\title{
An Educational Tool in Teaching Traditional Construction Technology: Modeling
}

\author{
(D) Nil Orbeyi \\ Mimar Sinan Fine Arts University, Vocational School, Architectural Restoration Programme \\ (D) Zeynep Ceran Keçici \\ Mimar Sinan Fine Arts University, Vocational School, Architectural Restoration Programme
}

Başvuru tarihi/Received: 03.07.2019, Kabul tarihi/Final Acceptance: 10.09.2019

\section{Introduction}

Starting from the ancient times, models have been used in many different civilizations throughout the history for various functions. The model of the Florence Cathedral, which was prepared before the construction of the structure in the $14^{\text {th }}$ century, is the first important example for the efficient use of the model as a structure design tool (Astbury 2014; Briggs, 1929). A miniature showing that the model of the Istanbul Süleymaniye Mosque (Necipoğlu 1986) dating back to middle of the 16 th century and the painting showing the model of the Roman - St Peter Cathedral dating back to the beginning of the $17^{\text {th }}$ century (Dunn, 2010) shows the use of the model as a tool of design as well as its use as a tool of presentation. Although the material of the models changed in time, its functions have always been similar; they have been used as a concrete tool in the design, production and presentation stages of the objects which are produced in the fields of art and design and planned to be $3 \mathrm{D}$. Today, the model is used as a tool to provide a clearer understanding of a concept in experimental studies (for example; the studies of seismic movements of structures) or in many areas requiring significant resources, time and investment expenditures such as stage and set decorations or architectural and engineering projects. In this study, the use of the model as an educational tool, in which the existing structure is analyzed in terms of size, shape, material and technology is discussed.

The study was carried out within the scope of Modeling Course; a dome dating back to the $18^{\text {th }}$ century of Ottoman Architecture was chosen as the main subject. The diameter of the sample dome made using molded technique is $6.00 \mathrm{~m}$ and the scale of the model made is $1 / 20$. The construction phases of the model were handled with a deductive approach based on the students' acquired personal skills during the study and/or during their lives and the structural information they gained during their education. Through this practice, it was aimed to improve the student's vision, perception, awareness, and level of knowledge and to gain the ability to analyze the structure and reinforce his/her theoretical knowledge (Fig. 1).

Even though the models are used in many different fields today; in the literature, the effects of model making on production and presentation were questioned (Gergin 2015; Özbaki et al. 2016), the use of different civilizations and disciplines in historical process were analyzed (Briggs, 1929; Astbury, 2014; Gergin, 2015), and their contribution to design education in different disciplines

\section{Abstract}

Models have been used as tools of design, exploration, presentation and education in many different disciplines in the historical process of many civilizations, ranging from architectural and engineering projects to stage and set design, from sculpture to modern technological designs. In this study, within the scope of the Modeling Course given in the Vocational School Architectural Restoration Program, a model of a dome dating back to the 18 th century in Ottoman architecture was constructed and the usability of the model as an educational tool in the analysis of the size, form, material and technology of an existing structure was discussed. In the first stage of the study, the components of the dome were produced in scale based on the samples from the same period, later in the second stage, a dome model was constructed by adhering to the construction technology. In addition, a survey was conducted to investigate the effects of model making on the learning process of the students. According to the data obtained from this study, which emphasizes the supportive aspect of learning in restoration education, in the case of simultaneous progression of theory and practice skills, it was observed that perception was positively affected, and knowledge and skills were developed in direct proportion.

öz

Maket; tarihsel süreçte pek çok uygarlıkta mimari ve mühendislik projelerinden sahne ve set tasarımına, heykelden, çă̆ımızdaki teknolojik tasarımlara kadar pek çok farklı disiplinde tasarım, keşif, sunum ve eğitim aracı olarak kullanılmıştır. Bu çalışmada Meslek Yüksekokulu Mimari Restorasyon Programı'nda verilen Maket dersi kapsamında Osmanlı mimarlığında 18. yüzylla tarihlenen bir kubbenin maketi yapılarak, var olan bir strüktürün boyut, biçim, malzeme ve teknolojik olarak çözümlenmesinde maketin bir eğitim aracl olarak kullanılabilirliği tartışılmıştır. Çalışmanın birinci aşamasında kubbenin bileşenleri dönem örneklerine göre ölçekli olarak üretilmiş, ikinci aşamada ise yapım teknolojisine bağlı kalınarak kubbe maketi tamamlanmıștır. Çalıșmada ayrıca maket uygulamasının öğrencinin ögrenme sürecine etkilerinin sorgulanması amactyla anket yapılmışır. Maket yapımının restorasyon eğitiminde öğrenimi destekleyici yönüne vurgu yapılan bu çalıșmadan elde edilen verilere göre teori ve uygulama becerilerinin eş zamanl ilerlemesi durumunda; algılamanın pozitif yönde etkilendiği, bilgi ve becerinin doğru orantılı gelişstiğ $i$ görülmüşı̈̈r.

Keywords: Model, dome construction techniques, education, Ottoman architecture Anahtar Kelimeler: Maket, kubbe yapım teknolojisi, ĕgitim, Osmanlı Mimarlı̆̆ 


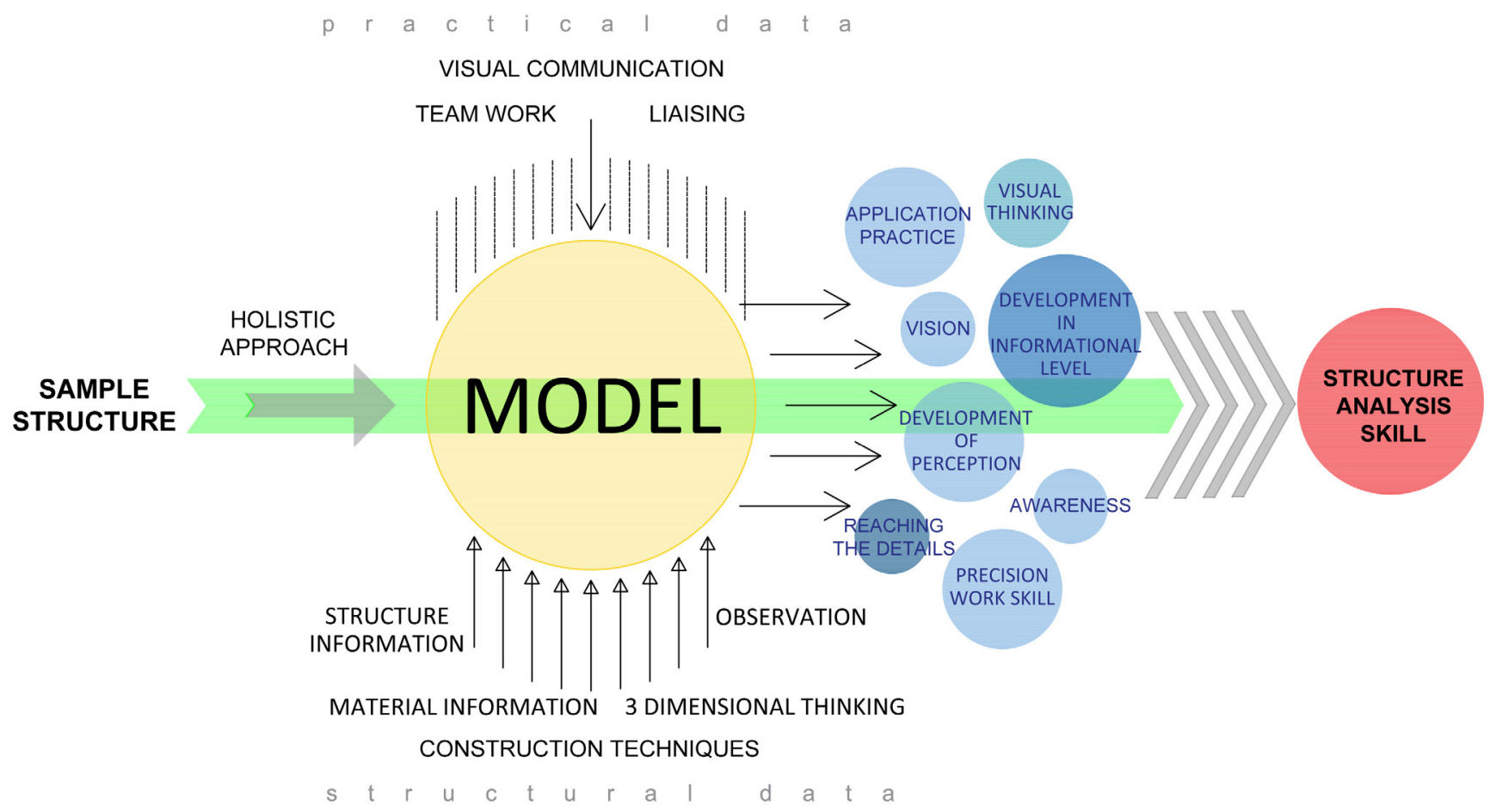

Figure: I Application process diagram. such as architecture, landscape architecture and urban planning were discussed (Düzenli et al. 2017). In this study which is unlike the other studies, the positive effects of the construction and use of the model on the cultural heritage (restoration) education were emphasized and the use of the model as an educational tool in a different discipline was debated.

\section{Methodology}

The study was conducted with the participation of 14 students (age 18-21) who took the Modeling elective course (1 hours of theo$r y$ and 2 hours of practice per week) in 2017-2018 Spring semester under the supervision of two instructors. Although the students have theoretical knowledge about the dome construction technology, they do not possess any practical experience. In this study, since it is aimed to analyze an existing structure, firstly the dome construction technology in Ottoman architecture was analyzed on structure templates together with the students and they have been informed about the application phases.

The study was completed in two separate stages. In the first stage, the components of the dome were produced in scale accord- ing to period samples. In the second phase of the study, the bricklaying dome was constructed by adhering to the construction technology and stages of the period. Preparation and application studies were completed in 3-hour courses over 6 weeks. The records of each course were kept and the process is documented with drawings and photographs. At the end of the study, a survey study was conducted to investigate the effects of the application on the learning process of the student. In the survey, students were asked questions to compare their levels of knowledge before and after the model implementation to evaluate the effects of the model on the learning process. The students were asked to answer the questions using 1 (barely), 2 (low), 3 (moderate), 4 (good), 5 (very good). The results were statistically evaluated and interpreted. Moreover, two tailed paired t-test is applied to check whether the difference between the samples are statistically significant for each question.

\section{Dome Construction Techniques in Ottoman Architecture}

Although it differentiated in terms of size, shape and material according to the 
civilization and period of the structure in the historical process, the dome was used as the primary cover component in many civilizations. When the literature is examined, it is seen that two main different techniques were used in the form of molded and non-molded dome for the Ottoman architecture (for documents about these techniques, see: Aktug 1995, 2006; Kolay and Çelik 2007). In this study, wood formwork, brick, khorasan mortar' as binder, tile or lead is used as top cover with mud plaster and/or stucco plaster for mold making. The brick weave, that starts from the dome's joist hanger line, is placed on the wooden dome pattern that was placed on wooden scaffolding prepared according to the dome geometry, is placed radially between the bricks using khorasan mortar and finished by placing a cone shaped keystone at the top of the dome. Brick sizes and the thickness of the mortar between the bricks varies according to the period in which the structure was built (for documents, see: Özyiğit, 1990; Tayla, 2007). It is known that the domes covering the small openings are built in 1 brick thickness and the domes that cover the large openings are generally built in 1.5-2 brick thickness. The thickness of the joint between the bricks is the thickness of 1 brick on the inner surface, and the outer surface is usually more than the thickness of 1 brick depending on the radial array. After the dome is completed, the inner and outer surfaces were plastered with 3-3.5 $\mathrm{cm}$ thick lime dense khorasan mortar. The inner and outer plaster is supported by inserting wide-headed nails into the surface of the dome. About $2 \mathrm{~cm}$ thick straw tempered clay mortar is plastered on the outer plaster, the lead or tile is covered and the dome construction is completed (Aktuğ 1995, 2006).

\section{Case Study: Construction Stages of a Dome Dating to the $18^{\text {th }}$ Century in Ottoman Architecture}

The steps of the molded dome technique described above were followed in the study. However, the dome pattern, which was removed since it did not have any post-construction function in traditional

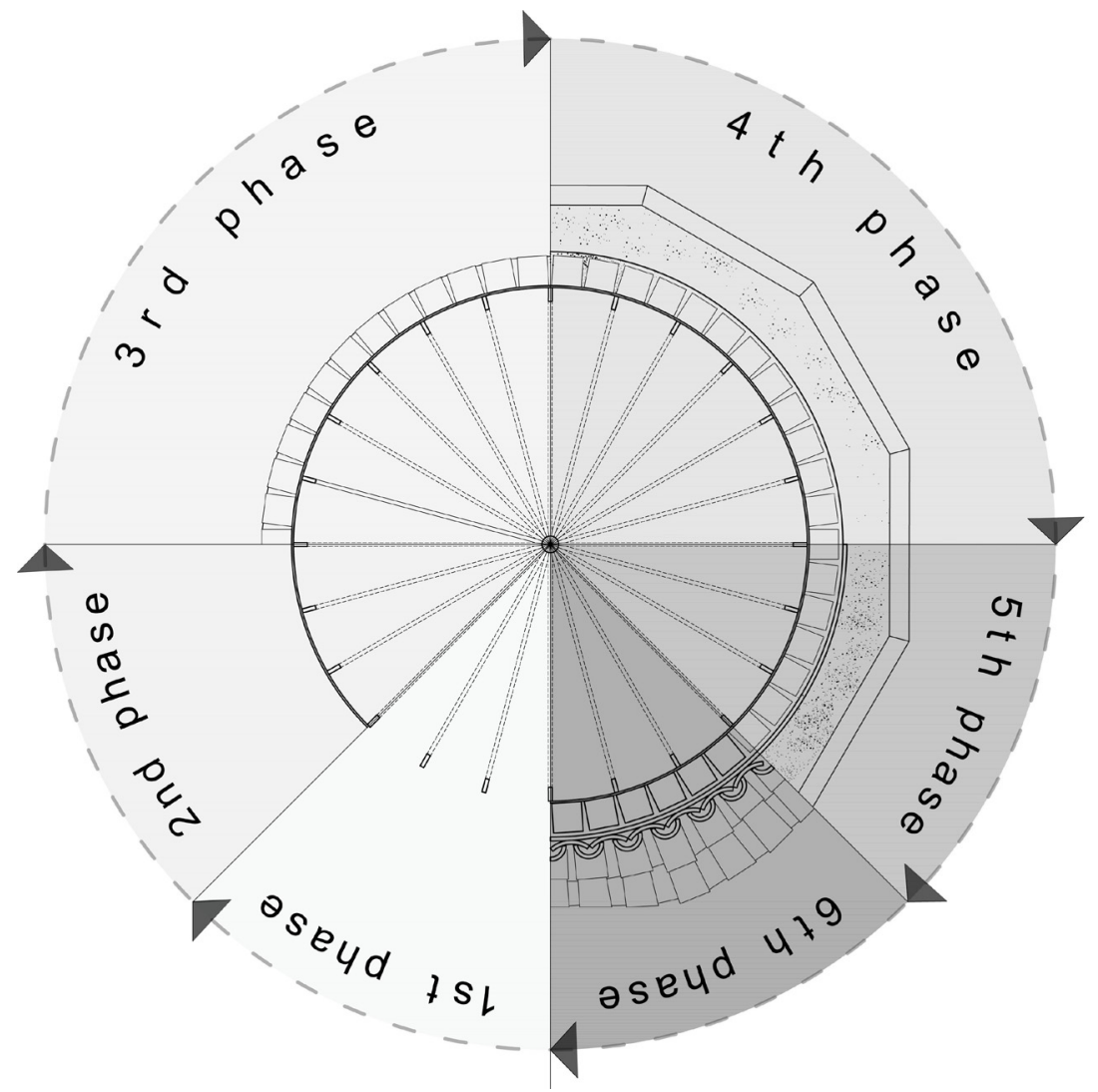

practice, was left on the model in order to be able to follow and display each stage visually. Dome model was primarily planned to be in six phase. These pieces which exhibit traditional molded dome making stages are as follows: ribs and veneers in the first two sections, brickwork in the third section, mud and fibered plaster in the fourth and fifth sections, and tile coating in the last section (Fig. 2).

\section{First Stage: Preparation}

The first stage of the study is the preparation of the materials to be used during the application. For this purpose, first of all, the application project of the dome (plan of the dome passing through the level of the spring line and the cross section of the dome) was drawn in digital (Fig. 3-4). In the plan drawing divided into 6 equal parts in such a way that production layers can be seen, it is determined which materials will be found in each layer and the model base is formed.

The division of labor between students was carried out alternately during the prepara-
Figure: 2

six phase circular schema.

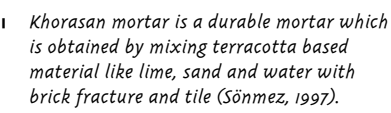
brick fracture and tile (Sönmez, 1997). 


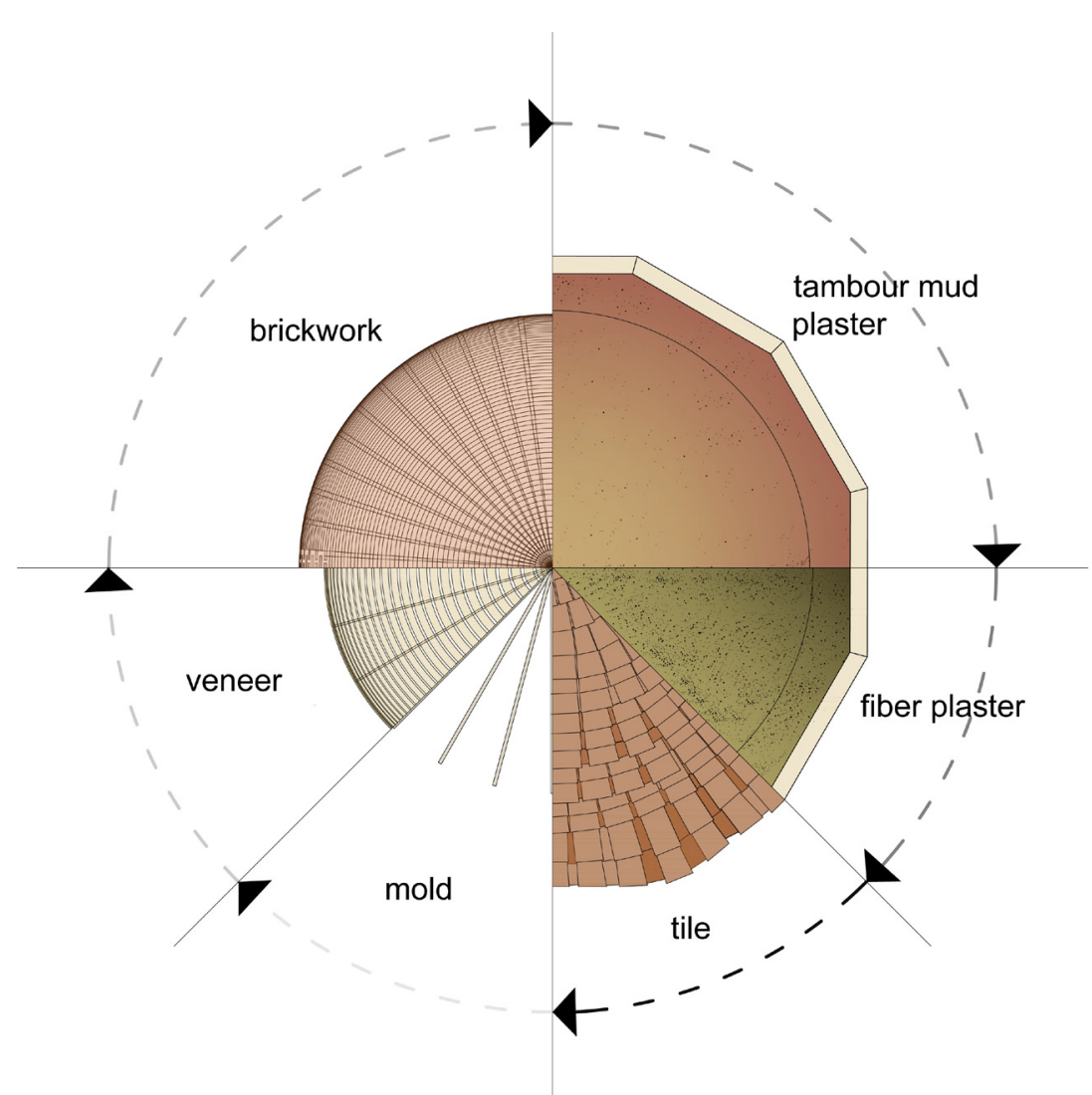

tory phase. The fact that the students took part in all stages enabled them to work with different materials. Materials required Figure: 3 six phase circular schema. Figure: 4 Dome cross section (Source: Authors, 2018). for application were prepared in a period of 9 hours.

Three basic materials were used in model making. The balsa tree for the ribs and veneers used in the original dome construction, the polymer clay for the bricks and tiles and the ceramic adhesive for mortar, mud plaster were used. While the materials made from polymer clay and balsa wood could be prepared independently from the application, the ceramic adhesive was prepared and applied during the construction phase due to the rapid freezing. The auxiliary materials used in addition to the main materials in the preparation phase are as follows; Cutting pad $(29.7 \times 42 \mathrm{~cm})$, utility knife or spatula, rubber roller $(10 \mathrm{~cm})$, balsa slat $(0.3 \times 0.3 \times 42 \mathrm{~cm})$, acetate (to make the clay easier to be removed from the pad), water, mixing bowl, stir bar, sanding and compass. The selection of the materials to be used in the model was determined visually according to various criteria besides the similarity to the original materials. The selection criteria of the building materials and the construction stages are as follows:

\section{a. Brick and tile making}

Both materials were made with terracotta polymer clay, no additional colorant was used. Polymer clay was selected for the following reasons:

- Self-drying without needing to be baked

- Good color properties, no need for extra colorants

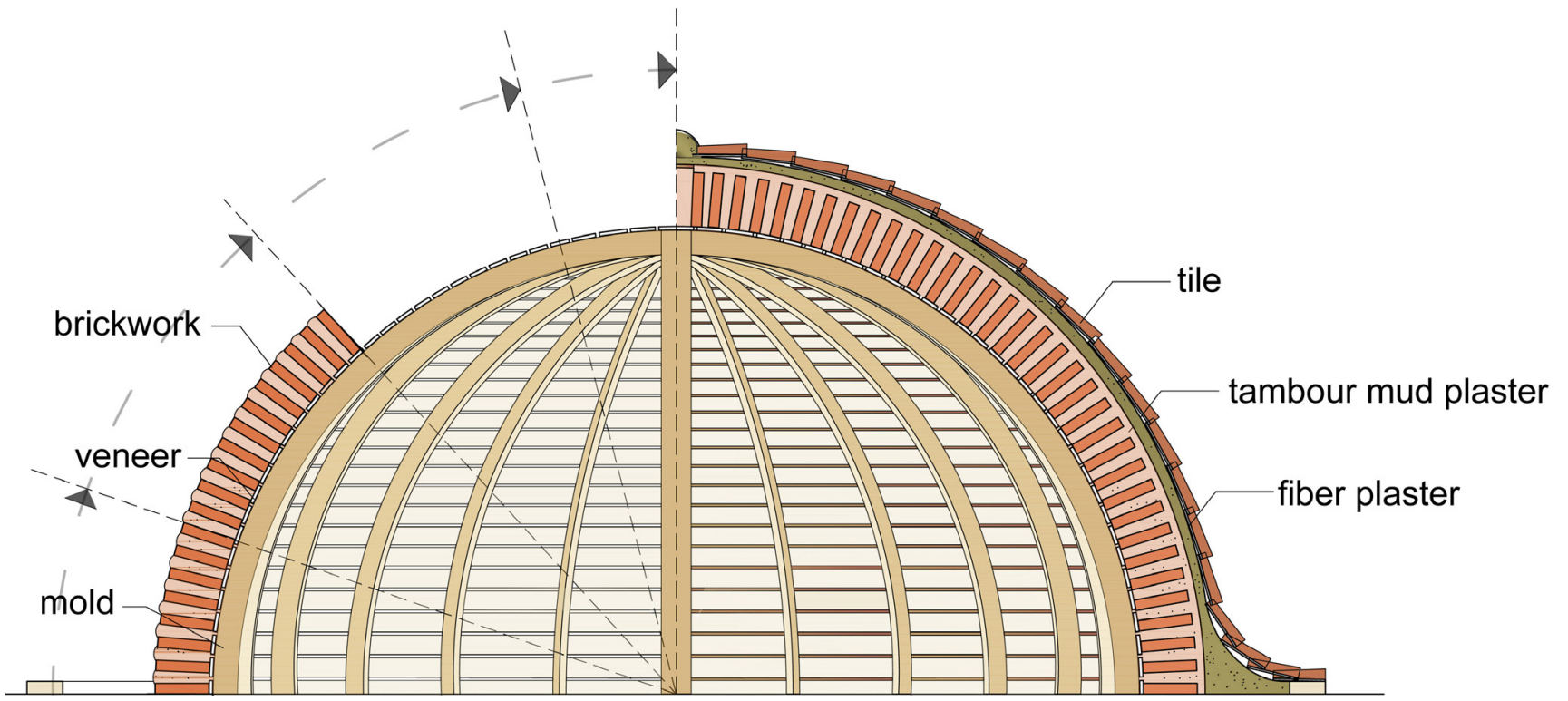




\section{- Brittle (after drying)}

- Easily shaped

- Easy to form with sandpaper after drying

At this stage, firstly the number of bricks to be used in the construction of the model was determined. According to the calculation, 800 bricks were required for the dome laying together with the wastes.

The original brick dimensions of the sample dome laying, dating back to the 18th century and $6.00 \mathrm{~m}$ in diameter, were taken as $27 \times 27 \times 5 \mathrm{~cm}$ depending on the period, therefore, the bricks were calculated as 15 $\mathrm{x} 15 \times 2.5 \mathrm{~mm}$ in the model to be made in $1 / 20$ scale. Since it was predicted that polymer clay will shrink during drying, the model bricks were planned to be cut in 17 x $17 \times 3 \mathrm{~mm}$. Before the preparation of the polymer clay, lanes were formed on the base to form the clay in the desired thickness and homogeneously. The distance between the laths and the number of lanes were calculated according to the targeted brick size. According to this, 4 balsa lathes of $3 \mathrm{~mm}$ thickness were fixed on the A3 cutting mat with acetate glued on them, with the gaps between in which the polymer clay will spread (Fig. 5a).

After the polymer clay was kneaded and brought to the desired consistency, it was spread with the help of rubber roller be- tween the balsa strips in the underlay and ensured that it would get a homogeneous appearance (Figure $5 b, c$ ). As the clay was still soft, it was allowed to dry for about one hour due to the fact that it could not be cut properly and brick dimensions were marked on clay (Fig. 5d, e). Then, the clay was cut according to the size of the brick using a utility knife and spatula. In order to prevent possible mis-measurements, a balsa trowel of $1.7 \times 8 \mathrm{~cm}$ was used (Fig. $5 f$ ). After the bi-directional cutting, the polymer clay was allowed to rest for about 1 hour to dry (Fig. 5g).

Similar operation was applied for the bricks produced with the same material. The bricks dating back to the $18^{\text {th }}$ century, with the dimensions of $18 \mathrm{~cm} \times 39.5 \mathrm{~cm}$ and $18 \mathrm{~cm} \mathrm{x} 39.5 \mathrm{~cm}$, were also produced in $1 / 20$ scale. The kneaded polymer clay was placed in the space between the $2 \mathrm{~mm}$ thick balsa strips fixed to the cutting mat to ensure that there was enough distance between them (Fig. 6a). Unlike the brick, the clay dough was cut to fit its size, so that it was thinner and easy to take shape. Meanwhile, the brick patterns used in the original application for the bricks in the lower row were prepared from the balsa tree. For the upper row of bricks, a cylindrical wooden rod of suitable size was used. After the clay was cut, it was shaped on these molds and left to rest for 24 hours.
Figure: 5

Production stages of bricks; $a$, b) preparation of cutting pad, $c, d$ ) spreading of clay dough between the slats, $e, f$, and $g$ ) cutting of clay.dough in brick size, $h$ ) sanding of drying. bricks (Source: Authors, 2018).
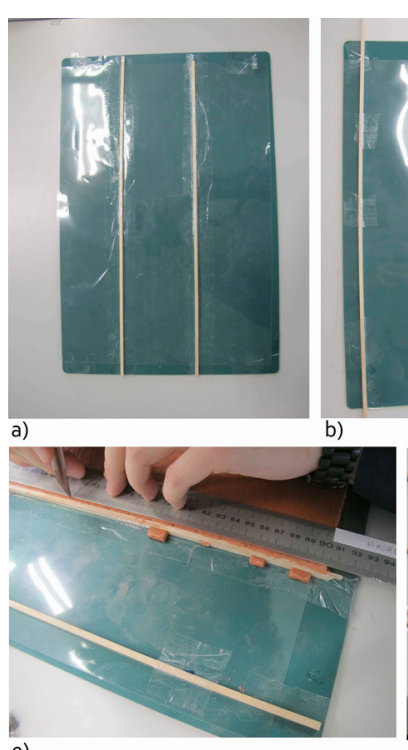

e)
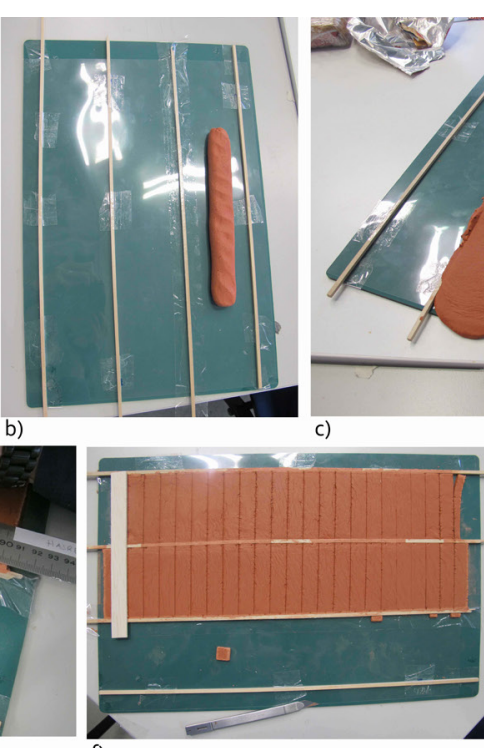
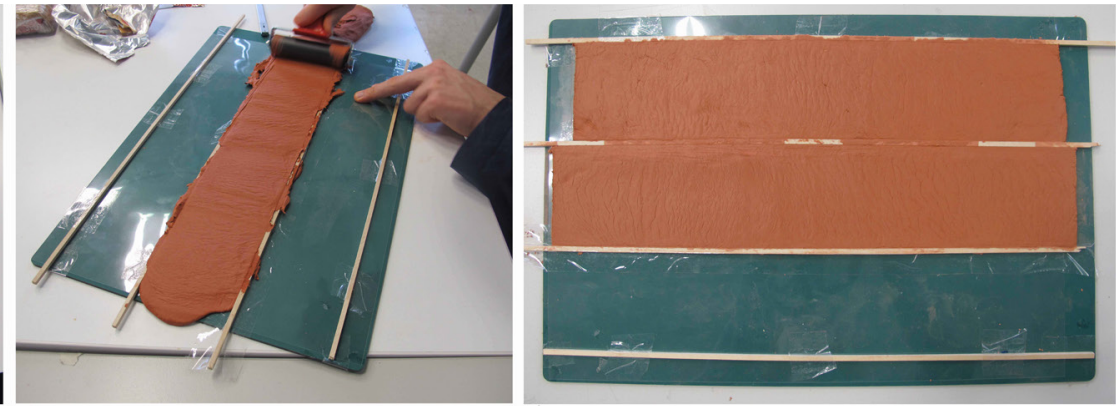

d)

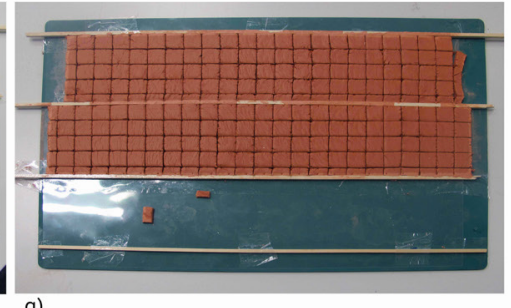

g)

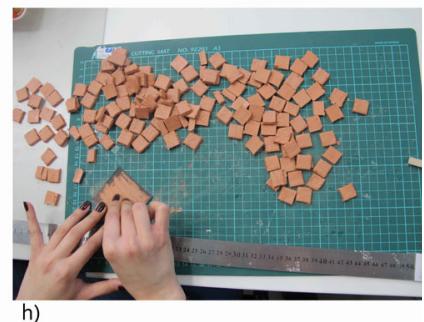

Sayı 28, Aralık 2019 


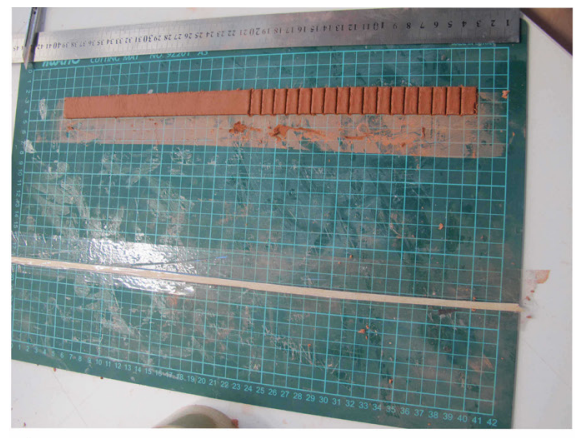

a)

Figure: 6

Production stages of tile; a) cutting of polymer clay, b, c) molding of top tiles, d) molds and tiles left to dry (Source: Authors, 2018).

Figure: 7

Mold making stages (Source: Authors, 2018).

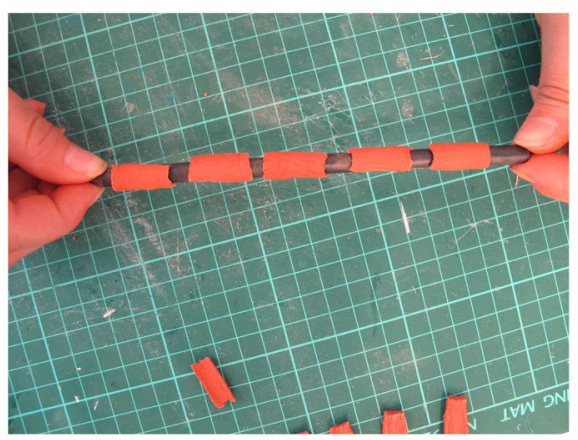

b)

The bricks and tiles were sanded after they were dried and cleaned from the surplus (Fig. 5h, 6b-c).

\section{b. Mold and polygonal pulley (tambour) construction}

The dome mold consists of a rib, veneer board and a support strip made entirely of balsa wood. Balsa tree was selected for the following reasons:

- Easily processed,

- Flexible structure,

- Compatible with original wood material due to its fibrous structure,

- Easy to form with sanding.

First, the template was prepared for the ribs according to the dimensions of the dome. Next, 50 ribs were cut using this template (Fig. 7a, b). The ends of the ribs were thinned with emery to ensure that the joint at the peak of the dome was smooth and has no openings. In addition to the ribs, a pillar from the balsa tree was placed in the midpoint for the mold to remain stable (Figure 7c). Simultaneously, strips of $5 \mathrm{~mm}$ width from $1 \mathrm{~mm}$ balsa tree were cut to be used as a cladding board. The length

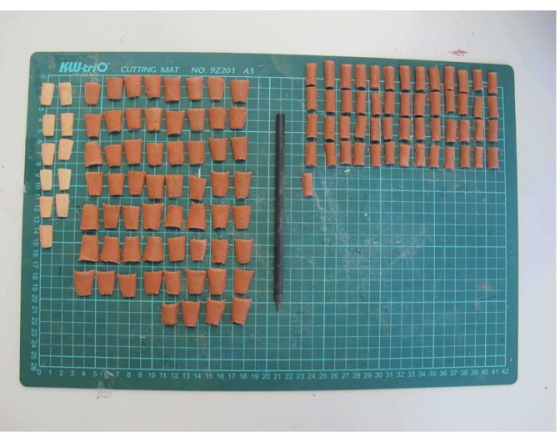

c)

of the cut balsa strips was determined according to the measurements taken over the mold. To this end, the template of the $1 / 8$ slice was first made with oil paper. The balsa pieces of $0.2 \times 0.5 \mathrm{~cm}$ dimensions were cut to the template and the veneers were formed. For the polygonal frame, firstly the twelve-hoop frame was digitally mapped, which will form the skirt of the dome. 12 pulley pieces from $1 \mathrm{~cm}$ thick balsa tree were cut and combined according to the template.

\section{c. Mortar, mud plaster and fibered plaster construction}

Mortars were prepared during application due to their quick drying characteristic. Ceramic adhesive was used in the construction of mortars. Ceramic adhesive was selected for the following reasons:

- Quick drying,

- Strongly adhesive,

- Can be colored.

When preparing the mortar to be used as the binder of the bricks, the powder obtained from the abrasive of the bricks was also added to the ceramic tile while the ceramic adhesive was in powder form.

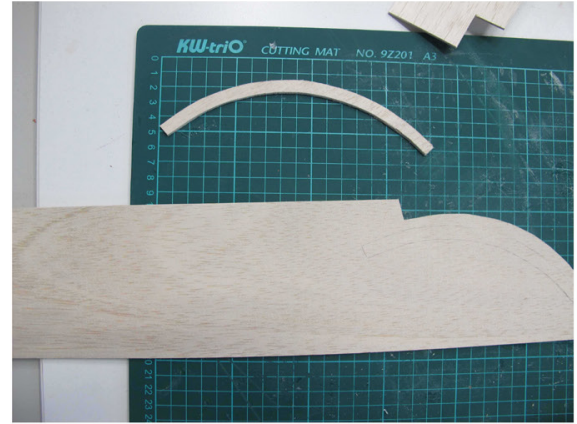

a)

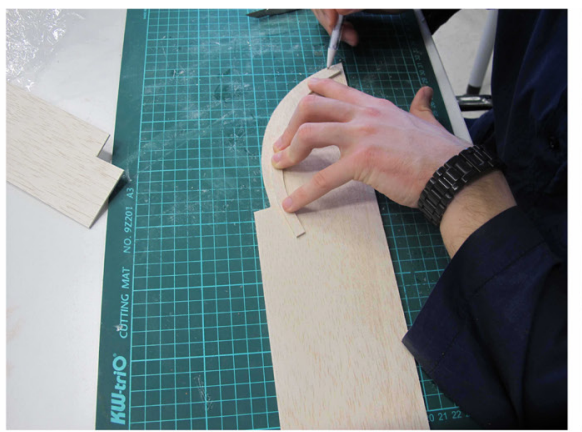

b)

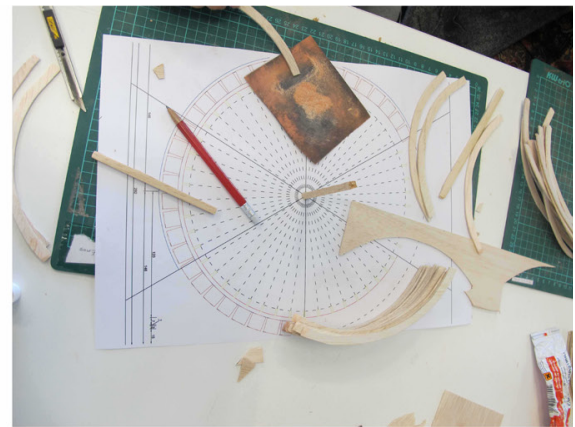

c) 


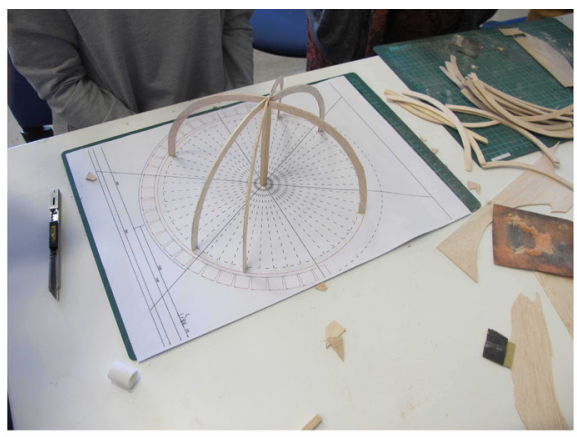

a)

Intensive consistency mortar used in the model consists of 8 scale ceramic adhesive, 1 scale sandpaper powder and 1 scale water. In the construction of the mud plaster, a $1 / 5$ ratio of water was added to the ceramic adhesive and a homogenous mixture was obtained before adding water-based brown color. The fibered plaster layer was prepared by adding 1 scale tow to the mixture that was prepared in the same proportion as the slurry plaster. These mixtures were prepared in small amounts during the construction of the dome and the processes were repeated when necessary.

\section{Second Stage: Practice}

At this stage, the division of labor between the students was made, and each student was allowed to participate in every stage of the practice. The dome construction was completed in 6 stages mentioned above. In addition to the auxiliary materials used in the preparation phase, tile molds, plywood $(45 \times 45 \mathrm{~cm})$, water based adhesive and sponge were used.

\section{Dome mold construction}

First of all, 50 ribs made in the preparation stage were attached to the plan drawing which was placed on both the ground and the floor using water based adhesive as well as supported with a stitch in the center (Fig. 8a). Half of the slice was left as a frame to be seen and the other half was covered with veneers. As in the original construction, the veneers were fixed with water-based adhesive by leaving spaces and the mold was completed.

\section{Bricklaying dome construction}

At this stage, the brickwork was prepared

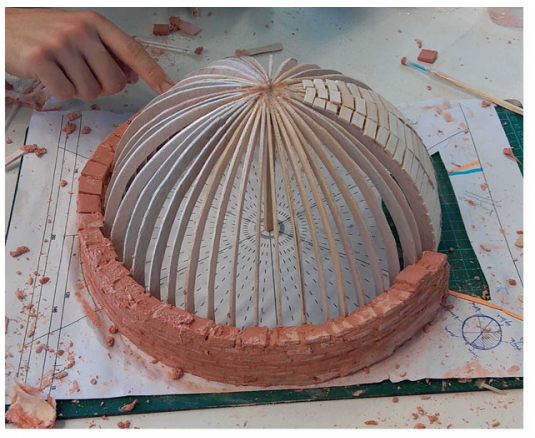

b) after preparing khorasan mortar. The cover started from the dome's joist hanger level (Fig. 8b). The first row of bricks was arranged along the outer line of the mold radially using a sufficient amount of mortar. In order to increase the strength, the second row of bricks was arranged in a tusk tenon manner, as in the conventional system, they have approximately $3 \mathrm{~mm}$ of mortar in the first row. In the bricklaying phase, attention was paid to the radial laying of the bricks in both plan and section plane. As in the conventional system, this radial aspect in the cross-section was achieved by increasing the density of the mortar near the outer surface of the bricks as the laying increases. In this way, $3 / 4$ of the dome was built with bricks (Fig. 8 c).

\section{Polygonal tambour making}

In the original application, the dome was placed on the lower structure (wall or arch system) in our application the dome was fixed on the $45 \times 45 \mathrm{~cm}$ square plywood base using water based adhesive. After this stage, the prepared twelve dome frame was fixed to the ground with water-based adhesive with equal spacing in all directions.

\section{Application of mud plaster}

The remaining 2/4 part of the dome was applied mud plaster. Dense viscous mud plaster was firstly filled into the space between the frame and the dome and later was applied to the dome surface as a thin layer with a thickness of 1-1.5 mm. Then, a slope was given to facilitate the crossing of the tile coating between the dome surface and the frame (Fig. 9a, b).
Figure: 8

Mold and dome construction stages (Source: Authors, 2018). 


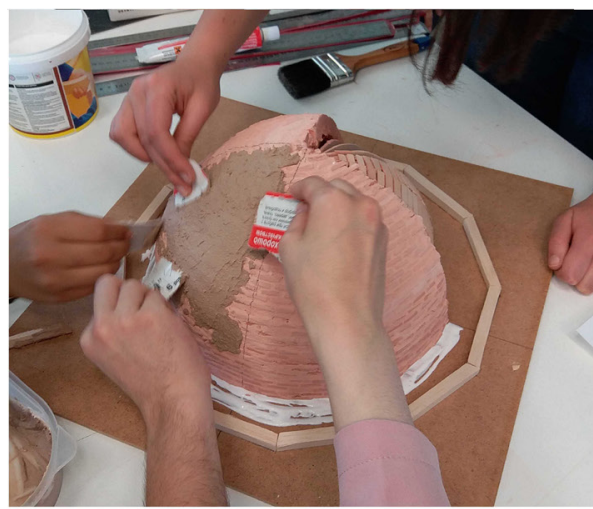

a)

Figure: 9

Application of polygonal frame, mud plaster, fibered plaster and tile coating (source: Authors, 2018).

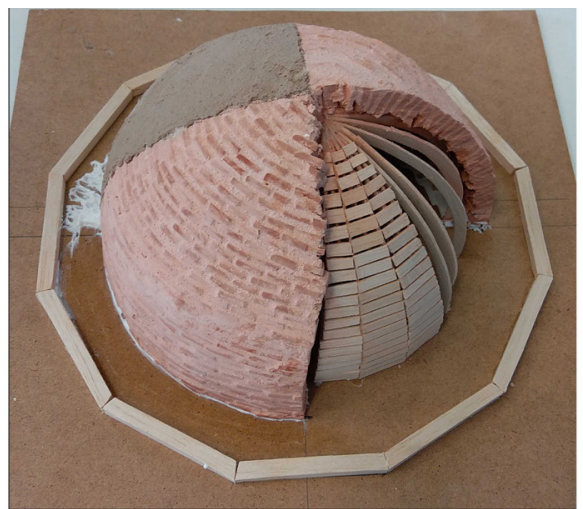

b)

\section{Fibered plaster application}

After the mud plaster was dried, fibered" plaster was applied to the last $1 / 4$ part of the dome. The fibered plaster was applied as a thicker layer than the mud plaster (Fig. 9b).

\section{Tile lining}

Tile coating was made in $1 / 8$ of the dome. The tiles were arranged from bottom to top as in the brick mesh. According to the period characteristics, wide tiles in the bottom row, cylindrical tiles in the upper row were placed in a manner that they will opposite each other. In the first line, large tiles were glued with water-based adhesive, and small-sized tiles were arranged in order to overlap the second part of the tiles. This sequence continues until it reaches the top of the dome. After the bottom row of bricks has been completed, the upper row tiles were placed in a manner that one for each of the two tiles, starting from the first line. The sequence continued until the top in this way and the tile coating was completed (Fig. 9c).

\section{Evaluation}

At the end of the study, in order to obtain the exact data in addition to the visual analysis of the educators, it was aimed to question the effects of the model making on the learning process of the students by conducting a survey. The following questions were asked to the students in the survey:

1. What level of knowledge do you think you possess about the properties of the "brick" used in an 18th century dome?

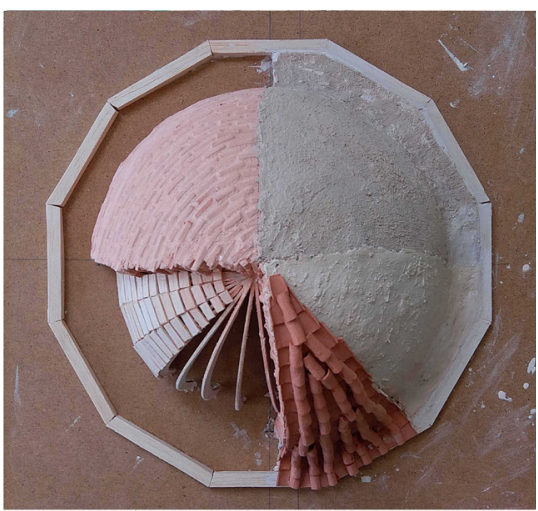

c)

2. What level of knowledge do you think you possess about the properties of the "mortars" used in an $18^{\text {th }}$ century dome?

3. What level of knowledge do you think you possess about the properties of the "tile" from cover materials used in an $18^{\text {th }}$ century dome?

4. What level of knowledge do you think you possess about the brick and bricklaying techniques in traditional dome construction?

5. What level of knowledge do you think you possess about the use and types of mortar in the traditional dome laying?

6. What level of knowledge do you think you possess about the construction techniques of the tile coating, which is one of the traditional dome coverings?

7. What level of knowledge do you think you possess about the layers in the dome and their relations with each other?

8. What level of knowledge do you think you possess about the dome laying techniques other than the applied laying technique (molded laying)?

9. What level of general knowledge do you think you possess about a traditional dome weave in general?

10. What level of knowledge do you think you possess about the reasons for the selection of the materials used in the application? 


\begin{tabular}{|c|c|c|c|c|}
\hline Question number & Avarage Score (Before the course) & Avarage Score (After the course) & Difference & Change in \% \\
\hline 1 & 1.64 & 3.79 & 2.15 & 43 \\
\hline 2 & 2.00 & 3.93 & 1.93 & 38.6 \\
\hline 3 & 1.93 & 4.00 & 2.07 & 41.4 \\
\hline 4 & 1.93 & 4.64 & 2.71 & 54.2 \\
\hline 5 & 1.43 & 4.00 & 2.57 & 51.4 \\
\hline 6 & 2.07 & 4.36 & 2.29 & 45.8 \\
\hline 7 & 1.93 & 4.43 & 2.5 & 50 \\
\hline 8 & 1.50 & 4.21 & 2.71 & 54.2 \\
\hline 9 & 2.07 & 4.50 & 2.43 & 48.6 \\
\hline 10 & 2.57 & 4.64 & 2.07 & 41.4 \\
\hline 11 & 3.86 & 4.71 & 0.85 & 17 \\
\hline 12 & 3.93 & 3.21 & -0.72 & -14.4 \\
\hline
\end{tabular}

11. What level do you think your level of interest in the subject is?

12. What do you think about the difficulty level of the dome model application?

\section{Statistical Overview}

At this stage, the average of the students' answers to the above questions before and after participating in the model application was taken and compared. The following obtained values are shown in the table below.

When the results were analyzed, it was seen that the highest increase (50\% or more) is in the answers given to the questions about the use of traditional materials, the technique of construction and the technical knowledge and application skills on

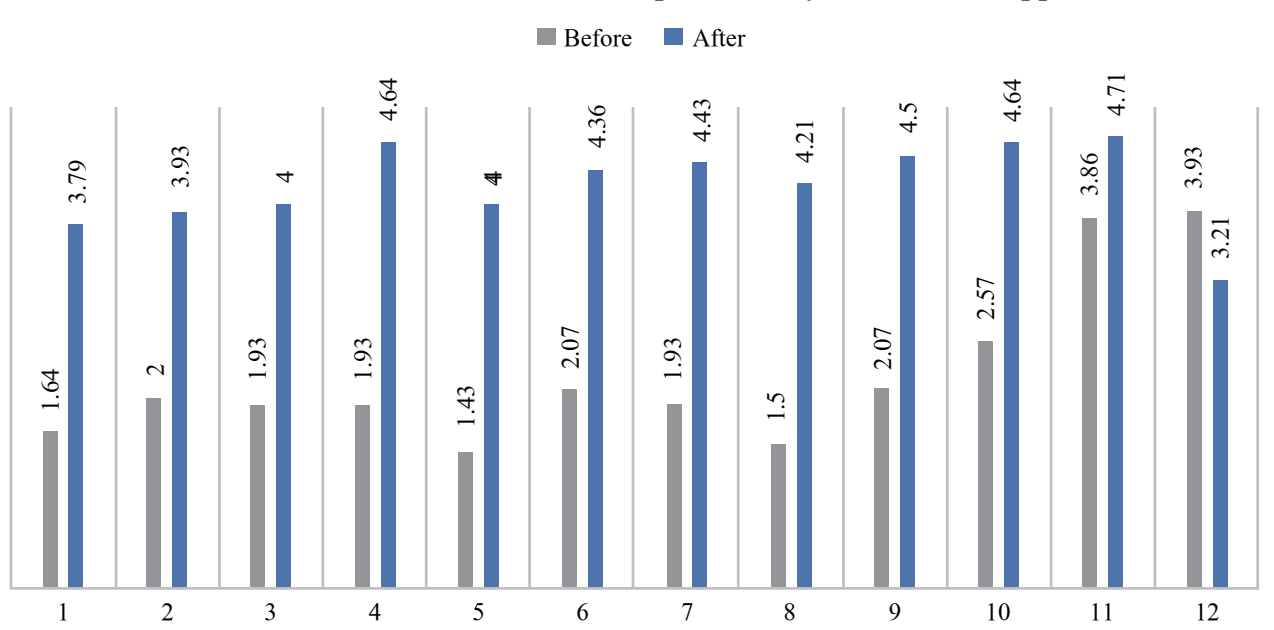

inter-layer relations. This is an indication that the making of the model contributes to the understanding of the traditional construction system and its practical application. While it is also observed that the application contributed to the theoretical knowledge gained in the learning process about the structural elements such as brick, mortar and tile (between $35 \%$ and $49 \%$ ), it can also be seen that this contribution is lower than the construction process and application. Another conclusion that can be drawn from the results is that the students who were involved in the construction of the model were affected positively by their interest in the site works in the restoration process of traditional buildings (or on-site practices). In addition, students who rated the difficulty of the application as approximately 4 before the application of
Table: I

Comparison of average scores given to questions.
Table: 2

Average scores given to questions. 
the model, rated the difficulty as "easier" with a decrease of about $15 \%$ at the end of the application. This is an indication that the students involved in the application process, in addition to the theoretical knowledge they have, are more likely to perceive the process as easy, since they were involved in the application process, due to the increased level of knowledge.

Apart from these questions, the students were asked a few general evaluation questions and asked directly about the contribution of the Modeling Course to restoration education. These questions are:

1. Do you think that this application will benefit you in different processes (building survey, quantity calculation etc.) in restoration applications?

2. Do you think this practice is useful for architectural restoration education?

3. Do you think the dome model application will contribute to your professional working life?

When the answers given were examined, it was seen that $97 \%$ of the students think that the dome model application that they were involved in will contribute to their professional working lives. In addition, it was also seen that they think the course was useful for the architectural restoration education (94\%), as well as in different processes of restoration applications,

Table: 3

$T$-test parameters for survey questions. etc. with a rate of $90 \%$. The importance of field work, one-to-one observation and implementation in restoration education cannot be ignored. In the feedback given by the students, it was seen that the theory described in the application was not fully understood before the actual application process, therefore, after the application, the students believe that if they encounter similar situation in their professional working lives (construction phase or problems encountered at this stage), this application will have a positive effect.

\section{T-Test}

Two tailed paired $t$ test is applied to show whether the difference between the results of survey A and survey B are statistically significant for each question (URL1). The assumptions for the analysis are listed below. Applicability of paired $t$ test to our problem is ensured through checking following points;

a) The dependent variable must be continuous: The score values for the test are in range 1-5 and can be assumed to be continuous

b) The observations are independent of one another: Each student filled out the survey independently.

c) The dependent variable should not contain any outliers: Since the range of the variable is $1-5$ there are no outliers in the analysis.

\begin{tabular}{|c|c|c|c|c|c|}
\hline Question No Survey A & Question No Survey B & Mean Difference & Standard Deviatin of Difference & P vaule & $\mathbf{P} \leq$ alpha \\
\hline 1 & 1 & 2.143 & 1.167 & $1.1379 \mathrm{E}-05$ & Yes \\
\hline 2 & 2 & 1.929 & 1.439 & 0.000237116 & Yes \\
\hline 3 & 3 & 2.071 & 1.542 & 0.000232515 & Yes \\
\hline 4 & 4 & 2.714 & 1.326 & $3.59006 \mathrm{E}-06$ & Yes \\
\hline 5 & 5 & 2.571 & 0.938 & $1.33236 \mathrm{E}-07$ & Yes \\
\hline 6 & 6 & 2.286 & 1.383 & $3.29775 \mathrm{E}-05$ & Yes \\
\hline 7 & 7 & 2.500 & 1.401 & $1.51898 \mathrm{E}-05$ & Yes \\
\hline 8 & 8 & 2.714 & 0.914 & 5.21944E-08 & Yes \\
\hline 9 & 9 & 2.429 & 1.158 & $2.75725 \mathrm{E}-06$ & Yes \\
\hline 10 & 10 & 2.071 & 1.328 & $5.818 \mathrm{E}-05$ & Yes \\
\hline 11 & 11 & 0.857 & 1.231 & 0.021825324 & Yes \\
\hline 12 & 12 & -0.714 & 1.139 & 0.035422664 & Yes \\
\hline
\end{tabular}


We assume significance level (alpha) as 0,05 for out paired test. Below table shows that the calculated $P$ value is less than the assumed alpha value per each question and therefore the results of Survey A and B is significantly different.

\section{Conclusion}

As in many disciplines, the theoretical teaching of a 3D object cannot be expected to give the same results as the practical teaching. In this study, it was revealed that the Modeling Course includes the instructional processes that enable the student to reinforce the knowledge learned in theory in the third dimension. In addition, the course contributed positively to the learning process and this opinion has been proven by the survey.

Undoubtedly, it is necessary to mention the weak points of the study as well, which are related to the application method. Because of the fact that the application of the model was a 14-week study only during the class hours and the time was limited, the decisions about material selection, size, shape and quantity calculations were taken by the instructors, which were then explained to the students with their reasons. The extent to which the level of learning will be affected (compared to this study) in which the students are able to decide the material, size and process may be the subject of another research. Furthermore, for the future studies, basing the model sample on the survey conducted by the students using the field study will strengthen the study. However, even in the presence of these methodological deficiencies, this study is sufficient to provide a basis for similar studies to be constructed. In addition, according to the findings obtained from this study, it can be concluded that if the theoretical and application skills progress simultaneously, the perception is affected positively and the knowledge and skills develop. Accordingly, this study also has the potential to be an approachable model that can contribute to the creation of the necessary infrastructure for the perception and conservation of cultural heritage, as this and other model appli- cations increase awareness as well as the architectural restoration education.

This study, where the students have the opportunity to experience this application on a small scale, can be defined as an approach model that can contribute to the future restoration education with its positive and encouraging aspects as well as its positive effect on education 


\section{References}

Aktuğ, İ. (1995). Ayazma Camisi İnşaat Defteri. 9. Milletlerarası Türk Sanatları Kongresi, 1, 79-89, Ankara: Kültür Bakanlığı Yayınları.

Aktuğ, K. İ. (2006). Osmanlı Belgelerinde Yer Alan Bazı Ahșap Yapı Malzemesi Üzerine Düşünceler. Sanat Tarihi Defterleri, 10, 23-45.

Astbury, J. (2014). Architects do it with models: the history of architecture in 16 models. Resource document. The Architectural Review. Retrieved from https://www.architectural-review.com/essays architects-do-it-with-models-the-history-of-architecture-in-16-models/8658964.article. Accessed 23 January 2019.

Briggs, S. M. (1929). Architectural Models I. The Burlington Magazine for Connoisseurs, 54 (313), 174-175, 178-181, 183.

Briggs, S. M. (1929). Architectural Models II. The Burlington Magazine for Connoisseurs, 54 (314), 245-247, 250-52.

Dunn, N. (2010). Architectural Model Making. London: Laurance King Publising.

Düzenli, T., Y1lmaz, S., \& Alpak, E. M. (2017). The Effects of Model Making on Design and Learning in Landscape Architecture Education. Eurasian Journal of Educational Research, 70, 121-134, http://dx.doi.org/10.14689/ ejer.2017.70.7

Gergin, A. (2015). Sanat ve Tasarım Alanlarında Maket Yapımının Tasarım, Üretim ve Sunum Așamalarına Etkileri. Yedi: Sanat, Tasarım ve Bilim Dergisi, 14(1), 157-168.

Kolay, İ. \& Çelik, S. (2007). Malzeme ve Teknoloji. In S Mülayim (Ed.), Bir Şaheser Süleymaniye Külliyesi (pp. 125-147). Ankara: TC Kültür ve Turizm Bakanlığı Yayınları.

Özbaki, Ç., Çağdaş, G. \& Kilimci, E. S. (2016). Maket ve Dijital Ortamda Tasarım Üretkenliğinin Karşılaștırılması. Megaron, 11(3), 398-411, https://doi.org/10.5505/megaron.2016.69188

Özyiğit, Ö., (1990). Alaturka Kiremidin Oluşumu. Ege Üniversitesi Edebiyat Fakültesi Yayınlar Arkeoloji ve Sanat Dergisi, V, 149-179.

Sönmez, N. (1997). Osmanlı Dönemi Yapı ve Malzeme Terimleri Sözlüğ̈̈. İstanbul: YEM Yayınları.

Tayla, H. (2007). Geleneksel Türk Mimarisinde Yapı Sistem ve Elemanları I. İstanbul: TAÇ Vakfı Yayınları.

URL-1. http://www.statisticssolutions.com/ manova-analysis-paired-sample-t-test/ 